\title{
INFLUENCE OF BORDER REGIONS RELATIONS ON THE TOURIST CHOICES OF THE POPULATION
}

\author{
Valentin S. KORNEEVETS ${ }^{*}$ \\ Immanuel Kant Baltic Federal University, Department of Socio-Cultural \\ Service and Tourism, Kaliningrad, Russia, e-mail: VKorneevets@kantiana.ru

\begin{abstract}
Alexander G. REDKIN
Altai State University, Faculty of Geography, Department of Recreational Geography, Tourism and Regional Marketing, Barnaul, Russia, e-mail: redkin.ag@yandex.ru
\end{abstract}

Tomash STUDZIENIECKI

Gdynia Maritime Academy, Gdynia, Poland, Morska 81/87, 81-225 Gdynia, Polonia, e-mail: t.studzieniecki@wpit.am.gdynia.pl

\section{Natalia A. ZAITSEVA}

Immanuel Kant Baltic Federal University, Department of Socio-Cultural Service and Tourism, Kaliningrad, Russia; Plekhanov Russian University of Economics, Department of Hospitality, Tourism and Sports Industry, Moscow, Russia, e-mail: zaitseva-itig@mail.ru

Citation: Korneevets, V.S., Redkin, A.G., Studzieniecki, T., \& Zaitseva, N.A. (2019). INFLUENCE OF BORDER REGIONS RELATIONS ON THE TOURIST CHOICES OF THE POPULATION. GeoJournal of Tourism and Geosites, 25(2), 569-579. https://doi.org/10.30892/gtg.25223-381

\begin{abstract}
The relevance of the research topic is determined by the differences in the conditions of Russian border regions development depending on their type, as well as certain tourism features in these territories. The purpose of the study is to identify and justify differences in the tourist preferences of border regions residents. The subjects of this research are so called development corridorborder region, represented by the Kaliningrad region, and the peripheral resource region, represented by the Altai Krai. The choice of regions is defined by the high level of tourist industry development. While doing the research, the authors of the article used general research methodology, quantitative and qualitative assessment, methods of economic, statistical, comparative and factor analysis, statistical groupings, and sociological observation. A statistical analysis revealed and analytically justified the difference in the level of socio-economic development of the Kaliningrad region and the Altai Krai. Development corridors show significant advantages in foreign trade and the size of the gross regional product, which confirms the correctness of the considered approaches to the classification of border regions. A sociological survey of tourist preferences showed differences in the tourist orientation of young people that correlate with the typology of border regions, which may define the developed programs for the marketing promotion of tourist destinations considering the main barriers.
\end{abstract}

\footnotetext{
* Corresponding author
} 
Keywords: cross-border cooperation, border regions, socio-economic development, Russian Federation, tourism

\section{INTRODUCTION}

The development of cross-border relations and cross-border cooperation is an important tool for overcoming the negative consequences of the peripheral nature of border regions. Therefore, the study of the cross-border relations experience and the development of cross-border regions are particularly relevant for the border regions of Russia. Only 5 out of 37 Russian regions are located on the border with the European Union (the Republic of Karelia, the Murmansk Leningrad, Pskov and Kaliningrad regions), but these regions are currently the most active participants in cross-border cooperation and initiate the development of integration processes between Russia and the European Union. The extended length of Russian land borders (including river and lake borders) of 24,625.3 km increases the importance of international cooperation for the state, especially cooperation between the Russian Federation and the border states, which confirms the relevance of research on cross-border and border regions.

Russian land border is the longest. It is $7512.8 \mathrm{~km}$ with Kazakhstan, $4209.3 \mathrm{~km}$ with China, and $3485 \mathrm{~km}$ with Mongolia. The minimum length of land borders with North Korea (DPRK) is $17.3 \mathrm{~km}$, South Ossetia is $70 \mathrm{~km}$, and with Poland it is $204.1 \mathrm{~km}$. However, in itself, the length of borderlines with the countries and regions does not affect the intensity of cross-border links. Thus, in terms of foreign trade turnover with Russia, Kazakhstan (with a maximum length of land borders) and Poland (with a minimum length of borders) are approximately equal: 15.5 billion US dollars with Kazakhstan and 14.5, with Poland (http://www.customs.ru/index.php?option=com_content\&view=article\&id= 13858\&Itemid=2095) respectively. During this period, according to the border service, the number of Russian tourists amounted to 3.4 thousand in Kazakhstan, and 32 thousand went to Poland, which absolutely does not correlate with the length of borders. Therefore, in order to make decisions about the intensification of relations between border and cross-border regions, it is necessary to have a good understanding of their specifics and development potential, including the clustering of goods production and services.

\section{RESEARCH METHODS AND MATERIALS}

The study of key issues of developing and adapting quantitative and qualitative indicators for assessing the competitiveness of the hospitality industry was carried out using some information sources like Tourism Market Trends UN WTO, The Travel \& Tourism Competitiveness Report 2017, materials of scientific conferences on the development of tourism in the regions, research papers on the role of tourism in the development of border areas. While studying the problems of quantitative and qualitative assessment of differences in tourist preferences of residents of border regions, traditional research methods were used. In addition, when conducting a comparative analysis of various types of border regions, general scientific methods of cognition were used, including theoretical studies (analysis, synthesis, aggregation) and empirical (observation, comparison), as well as a systematic approach, economic and statistical methods, comparative and factor analysis, statistical methods groupings, sociological observation.

\section{PUBLICATIONS' REVIEW}

\section{TYPES AND FEATURES OF BORDER REGIONS}

Based on the study of previously published works on the border regions development (Zubarevich, 2010; Klemeshev et al., 2004; Mezhevich, 2002; Korneevets 
et al., 2015; Korneevets et al., 2017), it can be concluded that these regions represent special types of territories, the specific development of which is determined by functional dualism of the border, combining barrier and contact functions. In case of unfriendly relations between the countries, the border can become an insurmountable barrier to the communication, as it happened with the Russia - Ukraine border. When the cooperation between neighbors is developing, like between Russia and China, growing flows of goods, services, and the population pass across borders. In such cases, the border regions may become "development corridors" (Klemeshev et al., 2004). That is, the functionality of the boundaries is dynamic and may change either to increase the contact function, or to enhance the barrier function of the boundary.

At the same time, as noted by J. Berdell and An. Goshal (2015), border regions may be either active areas of commercial exchange that contribute to the development of their larger economies, or, on the other hand, they may be relatively isolated peripheral areas where their stagnation reduces national progress as a whole. We agree with Cooper and Rumford (2013), who believe that boundaries should be considered as mechanisms of connectivity and interaction, but not as markers of separation. The unique location of cities near the borders (on the example of Gdansk and Kaliningrad), according to Studzińska and Domanevsky (2016), can be a major factor in the development of border regions. That will affect the transformation of the border function by increasing its permeability and will be a resource for the development of local communities. J. Friedmann's (1968) typology of the border regions which is recommended to be applied to Russian ones (with a land border), distinguishes between the following types of regions: core regions, transitional developing regions; transition crisis regions; peripheral resource regions; development corridors. St. Petersburg and the Leningrad Region have the highest level of development of crossborder ties, which we consider as a single territorial system that belongs simultaneously to core regions and development corridors. The function of the development corridor here is implied in the conditions of a developed industrial, scientific, educational, and sociocultural potential of St. Petersburg, which is also the second most important center of inbound foreign tourism in Russia after Moscow. The regions - development corridors in Russia include the Kaliningrad region and the Primorsky Krai, which connect other Russian regions with foreign countries in the west and east of Russia, respectively, and the development of these two regions is largely determined by their transit role.

Gumenyuk and Studzieniecki (2018) note that transport is both a tool for strengthening cross-border links, and an object of cross-border cooperation, which includes joint transport projects and the creation of transport and logistics corridors. A number of researchers (A.P. Klemeshev, G.M. Fedorov) additionally distinguish a special subtype of regions - development corridors located not between national regions (as in J. Friedmann), but between them and the core regions of foreign countries.

These regions include, on the one hand, the Kaliningrad region (as a development corridor between Russia and the EU), and on the other, the Baltic Euro-region, which functions as a development corridor in the economic system of the Baltic space (Klemeshev et al., 2004). Given transitional developing regions, transitional crisis regions and peripheral resource regions, we can distinguish various groups of border regions (with land borders) according to their development, calculated on a set of indicators of GRP and foreign trade per capita, the ratio of nominal wages to the cost of consumer goods and services , population migration dynamics (Korneevets, 2010).

\section{REVISION OF THE TYPOLOGY OF BORDER AREAS CONSIDERING THE CURRENT FEATURES OF THEIR DEVELOPMENT}

Given the specificity of the border regions development, manifested in various 
combinations of border barrier and contact functions, a common typology of Martinez (1994) can be added to the classification of border (with land border) regions according to the degree of development of their relations with neighboring regions. Based on the classification of B. Van der Velde (1997), a number of researchers, including V. Korneevets and N. Zaitseva, distinguish the following types of Russian border regions (Korneevets et al., 2017; Zaitseva et al., 2016).

A) alienated border regions: the Republic of the North Caucasus (except for Dagestan) and, in part, the border regions of Russia and Ukraine;

B) co-existing border regions (Dagestan; a number of regions on the borders with China and Mongolia);

C) interdependent border regions (regions on the borders with Kazakhstan, Belarus and partly with the countries of the European Union, the trend in this direction is in regions bordering on China);

D) there are still no integrated border regions, although all regions on the borders with Kazakhstan and Belarus have the same prerequisites, to the greatest extent - the Smolensk region.

The typology of border regions was further developed in the works of $\mathrm{L}$. Osmolovskaya, who transforms definitions of types of border regions in accordance with current trends and complements typology with a fifth type of border regions: open (barrier-free) border regions. First of all, interior regions within the European Union may be related to this type of border region (Osmolovskaya, 2016). In general, the factors that determine the development of relations between various subjects located on both sides of the border, the development of border regions and the formation of crossborder regions are diverse. We can distinguish between objective and subjective, internal and external, general, private and special factors.

They can be classified in accordance with the functional structure of the society depending on which of the territorial socio-economic systems is involved in the formation of cross-border regions. It is most advisable to consider political, economic, social, demographic, ethnic, ekistics, environmental and natural factors. In some cases, it is possible to use the basic factors of spatial development identified by the World Bank, which can fall into three main groups, as states N. Zubarevich (2010):

A) density, taking into account the agglomeration effect;

B) economic distance, determined by remoteness from the global and domestic markets;

C) various institutional divisions, including the barrier function of borders.

Although these factors are most often considered in relation to the development of countries and national regions, since the latter include the border regions, it can be argued that these groups of factors are significant to various types of cross-border regions. At the same time, as Voloshenko (2018) notes, the border position of a region and its assumed distance or isolation (for example, in our study such are the Kaliningrad region and the Altai Krai) from the largest industrial-technological, resource and production centers places special demands on balanced development of such territories from the standpoint of ensuring internal growth and socio-economic development.

Considering the development of border regions, it should be noted that in the early stages tourism can be one of the mechanisms to facilitate cross-border cooperation followed by transformation into a diversified economic center due to the multiplication effect and the formation of a favorable investment climate, followed by a transition from alienated to integrated regions. At the same time, the administrative focus on tourism in transboundary regional development can be considered as a tool for gaining socio-economic and political power through a commitment to broader participation in the development of international cooperation (Stoffelen et al., 2017; 
Ilies et al., 2018). Conversely, borders can serve as additional obstacles for sustainable development if they lead to situations where "different interest groups in the region are differently involved in the process of cross-border regionalization".

\section{OUTCOMES OF THE RESEARCH \\ ASSESSMENT OF THE STATE AND DEVELOPMENT PROSPECTS OF THE BORDER REGIONS OF THE RUSSIAN FEDERATION}

Previously, the author's research showed that in addition to St. Petersburg, the Leningrad and Kaliningrad regions, Belgorod and Tyumen regions are among the most developed border regions of Russia. The level of development of such frontier industrial-agrarian regions, as Orenburg, Chelyabinsk and Novosibirsk, as well as a number of raw material regions (Murmansk Region, Karelia, Khabarovsk Krai) is above the average. Accordingly, they have a greater potential of their own for cross-border cooperation. The southern regions of the European part of the country and the Krasnodar Krai are of the average level of development. All of them have a certain potential for the development of cross-border relations. A low level of development is characteristic of the three border regions located on the border with Belarus (the Pskov, Smolensk, Bryansk regions), which belong to transitional crisis regions, and the Kurgan region, which is a group of peripheral resource regions.

In the east of the country, as far east as from the Altai Krai and the Jewish Autonomous Region, the regions have a low and a very low (Tyva) level of development. All the border republics of the North Caucasus belong to regions with a very low level of development; their potential for cross-border cooperation is poor, which makes it possible to attribute them to transitional crisis regions.

All regions of the Russian Federation bordering on Kazakhstan can be attributed to peripheral resource regions, less densely populated and less developed, the economy here is primarily industrial-agrarian, and a number of regions are characterized by an increased specific weight of the extracting industries. Among the transitional and peripheral resource regions, in addition to developing and crisis ones, we can distinguish an intermediate type - stable regions, which do not show either serious crisis phenomena or dynamic development. These regions include the Krasnodar and Altai Krais, the Astrakhan and Novosibirsk regions. It should be noted that in conditions of political crisis situations leading to sanctions policy (border regions with the European Union) or interrupting economic ties (border regions with Ukraine), the typology of border regions may change from developing to stable. But most often, this influence has a short-term effect, prior to the search for new trading partners and markets.

\section{COMPARATIVE ANALYSIS OF VARIOUS TYPES OF BORDER REGIONS OF THE RUSSIAN FEDERATION}

In their studies, the authors conducted a comparative analysis of two Russian border regions belonging to different classification types, based on the above-mentioned analysis of approaches to the typology of regions (Ilies et al., 2014). The objects of research are the Kaliningrad region, which has common borders with the states of the European Union Poland - 236.3 km and Lithuania - $288.4 \mathrm{~km}$, and the Altai Krai, which has a border with Kazakhstan - $844 \mathrm{~km}$, a member of the Commonwealth of Independent States (Figure 1). At the same time, despite the shorter length of the borders, the Kaliningrad region has more border-crossing checkpoints: 14 in the Kaliningrad region and 13 in the Altai Krai. The density of land border-crossing checkpoints in the Kaliningrad region is much higher than in the Altai Krai: from $50 \mathrm{~km}$ to one checkpoint on the border with Poland, up to $170 \mathrm{~km}$ on the border with Kazakhstan. In accordance 
with J. Friedmann's typology of the regions and the previous studies, the Kaliningrad region belongs to development corridors, while the Altai Krai, as less densely populated and less developed, has an industrial-agrarian economy, belongs to peripheral resource regions with $\mathbf{1 7 . 4 \%}$ in the structure of the gross regional product against $4.8 \%$ for the Kaliningrad region. The population density in the Altai Krai (table 1 ) is 14.1 people / km², which is significantly lower than the Kaliningrad region with its 65.2 people / $\mathrm{km}^{2}$.

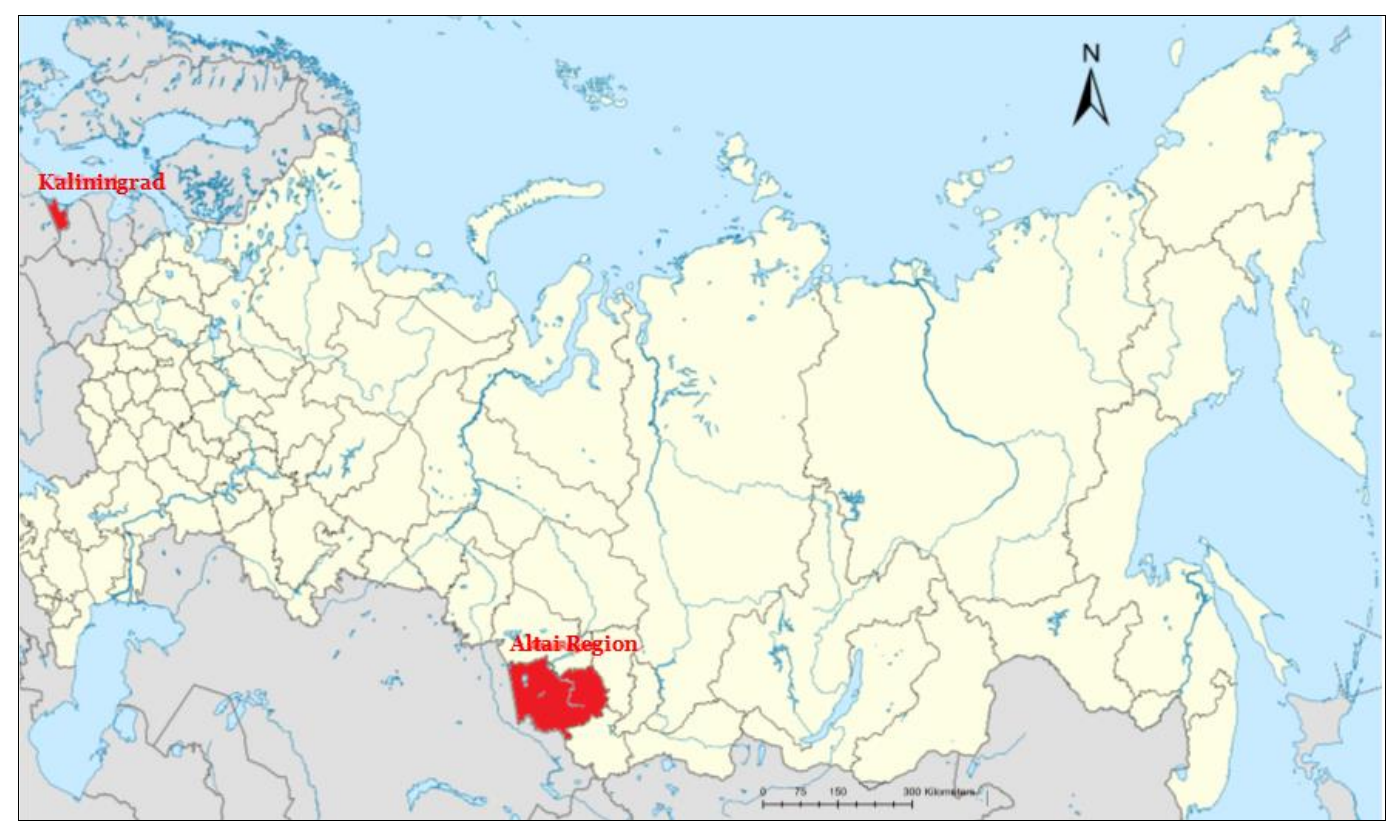

Figure 1. Geographic location of the Kaliningrad region and the Altai Krai

Table 1. Socio-economic characteristics of the Kaliningrad region and the Altai Krai (Data source: Complied and calculated on http://www.gks.ru/bgd/regl/b17_14s/IssWWW.exe/Stg/.doc)

\begin{tabular}{|l|c|c|}
\hline \hline Indicators & The Kaliningrad region & The Altai Krai \\
\hline Total area, thousand $\mathrm{km}^{2}$ & $\mathbf{1 5 , 1}$ & 168,0 \\
\hline Population, thousand people (as of January 1, 2017) & 986,3 & 2365,7 \\
\hline Population density, people / $\mathrm{km}^{2}$ (as of January 1, 2017) & 65,2 & 14,1 \\
\hline The largest cities, thousand people & Kaliningrad - 467,3 & $\begin{array}{c}\text { Barnaul - 633,3 } \\
\text { Biysk - 203,1 } \\
\text { Rubtsovsk - 145,3 }\end{array}$ \\
\hline National population structure, 2010 census, \% & $\begin{array}{c}\text { Russians - 86,4 } \\
\text { Ukrainians - 3,7 } \\
\text { Belorussians - 3,6 }\end{array}$ & $\begin{array}{c}\text { Russians - 93,9 } \\
\text { Germans - 2.1 } \\
\text { Ukrainians - 3,7 }\end{array}$ \\
\hline Per capita cash income (per month), rub. & 25903 & 21485 \\
\hline Consumer basket (at the end of the year) & 14547 & 12721 \\
\hline $\begin{array}{l}\text { The ratio of cash income to the cost of the } \\
\text { consumer basket }\end{array}$ & 1,78 & 1,69 \\
\hline Gross regional product, per capita, rub. & 337990 & 206712 \\
\hline $\begin{array}{l}\text { Revenues of the consolidated budget of the subject, } \\
\text { mln. rub. }\end{array}$ & 85509 & 99465 \\
\hline $\begin{array}{l}\text { Revenues of the consolidated budget of the subject } \\
\text { per capita, rub. }\end{array}$ & 86697 & 42045 \\
\hline Foreign trade turnover, mln. & 7047 & 968,4 \\
\hline
\end{tabular}


Considering the demographic, ethnic, ekistics factors of border regions development, it should be noted that the dominance of the titular nation in the national composition of the population does not make much difference between regions: $86.4 \%$ of Russians in the Kaliningrad region and 93.9\% in the Altai Krai. The structure of settlement in the Altai Krai is more optimal than in the Kaliningrad region, where 47.4\% of the region's inhabitants live in the regional center (26.8\% in Barnaul), and the population in the secondary urban center is almost 12 times higher than in the major one (in the Altai Krai, this ratio is slightly higher than 3). The most significant differences between regions are manifested in the demographic situation: the Kaliningrad region is characterized by increasing migration dynamics - from $+4 \mathrm{ppm}$ in 2008 to $+10 \mathrm{ppm}$ in 2016, in contrast to the growing negative migration balance in the Altai Krai (respectively: $-\mathbf{2 . 0}$ and $\mathbf{- 2 . 7} \mathrm{ppm}$ ). Since 2000, the population in the Altai Krai has decreased by $10.8 \%$, while in the Kaliningrad region it has increased by $2.9 \%$.

Regarding the Kaliningrad region, it should be noted after G. Fedorov (2018) that the maritime situation clearly has a positive effect on its more favorable demographic and socio-economic characteristics. In general, the border regions, including the Altai Krai, being peripheral (according to the polarization hypothesis), find themselves in a demographically more difficult position than the internal ones (especially if the barrier functions prevail over the contact ones). To identify the subtype of the border region, we will conduct a comparative assessment of the regional development dynamic factors for both the Kaliningrad region and the Altai Krai in 2008 and 2016 (Table 2).

Table 2. Dynamic factors of regional development of the Kaliningrad region and the Altai Krai in 2008 and 2016 (Data source: Complied and calculated on http://www.gks.ru/bgd/regl/b17_14s/IssWWW.exe/Stg/.doc)

\begin{tabular}{|c|c|c|c|c|c|}
\hline \hline & & $\begin{array}{c}\text { GRP per } \\
\text { capita } \\
\text { (thousand } \\
\text { rubles) }\end{array}$ & $\begin{array}{c}\text { Foreign trade } \\
\text { turnover per } \\
\text { capita } \\
\text { (US dollars) }\end{array}$ & $\begin{array}{c}\text { The ratio of nominal } \\
\text { wages to the cost of } \\
\text { consumer goods and } \\
\text { services }\end{array}$ & $\begin{array}{c}\text { Migration growth } \\
(+) \text { or loss (-), pers. } \\
\text { per 10oo total } \\
\text { population }\end{array}$ \\
\hline \multirow{2}{*}{$\begin{array}{c}\text { The Kaliningrad } \\
\text { region }\end{array}$} & 2008 & 193,9 & 10799 & 2,06 & $+4,0$ \\
\cline { 2 - 6 } & 2016 & 338,0 & 7140 & 2,02 & $+10,0$ \\
\hline \multirow{2}{*}{ The Altai Krai } & 2008 & 107,4 & 790 & 1,61 & $-2,0$ \\
\cline { 2 - 6 } & 2016 & 206,7 & 409 & 1,67 & $-2,7$ \\
\hline
\end{tabular}

As can be seen from table 2, the social development factors of the two border regions are somewhat better in the Kaliningrad region, since the level of per capita cash income and the ratio of income and nominal wages to the cost of consumer goods and services are higher than in the Altai Krai. Although it is worth noting the decline of this indicator in the Kaliningrad region from 2.06 in 2008 to 2.02 in 2016, against the growth in Altai Krai from 1.61 to 1.67 , which is primarily due to the greater orientation of the Kaliningrad regional consumer market for imported goods, which in the conditions of decrease in the exchange difference of the national currency led to a more significant increase in prices. Economic factors were described with three main indicators, i.e. gross regional product, foreign trade turnover and the consolidated budget of the region. All economic indicators of the effectiveness of regional development per capita are significantly higher in the Kaliningrad region.

The gross regional product in 2016 amounted to 338 thousand rubles per capita (in the Altai Krai - 206.7 thousand rubles), and the revenue of the consolidated budget is 86.7 thousand rubles per capita (in the Altai Krai it is 42.0 thousand rubles.). But the difference in the gross regional product between the regions gradually decreases: if in 
2008 the gross regional product per capita of the Altai Krai was 55.4\% of the level of the Kaliningrad region, then in 2016 this figure was $61.1 \%$. However, this was not due to higher rates of economic development, but due to the multidirectional dynamics of population change: growth in the Kaliningrad region and decline in the Altai Krai.

The most significant difference between the regions is manifested in the foreign trade turnover of the regions: $\$ 7,140$ per capita in 2016 in the Kaliningrad region and only $\$ 409$ in the Altai Krai, with an average Russian figure of $\$ 3,215$.

These economic indicators confirm the Kaliningrad region to be one of development corridors, and the Altai Krai to be a stable peripheral resource region in accordance with the considered typology of border regions.

\section{EVALUATION OF THE TOURIST CHOICES OF THE RF BORDER REGIONS POPULATION (ON THE EXAMPLE OF THE KALININGRAD REGION AND THE ALTAI KRAI)}

The tourism sector in the Kaliningrad region and the Altai Krai is quite developed and has developed dynamically in recent years, especially after 2013. In 2016, 1,300 tourists visited the Kaliningrad region and 2050 people came to the Altai Krai (http://tourism.gov39.ru/; http://alttur22.ru/pages/turizm-v-cifrah-v-altayskom-krae). In the national tourist rating of the Information Communications Center "Rating" for 2016, Altai Krai ranks the $7^{\text {th }}$, while the Kaliningrad Oblast is the $9^{\text {th }}$ (http://russiarating.ru/info/10950.html). Although Altai Krai is rated higher for tourist attractiveness, the density of tourist flows is higher in the Kaliningrad region: 1.32 tourists per region or 86 tourists per $\mathrm{km}^{2}$. In the Altai Krai, these figures are 0.9 tourists per capita and 12.2 tourists per $\mathrm{km}^{2}$. At the same time, both border regions specialize in health tourism and have areas with the status of federal resorts: for example, Belokurikha in Altai or Svetlogorsk in the Kaliningrad region.

The number of sanatorium and recreation centers in the Altai Krai significantly exceeds that in the Kaliningrad region. Also, in these regions gambling and entertainment zones have been established. Both regions have a high level of development of rural and event tourism. However, it should be noted the low level of inbound foreign tourism and, if in the Kaliningrad region it reaches a figure of $10 \%$ of the total tourist flow, in the Altai Krai the share of foreign tourists is only $0.5 \%$. When it comes to outbound tourism there are significant differences in travel destinations. In the Altai Krai, the share of travel to other Russian regions is high in sales of package tours, $72.2 \%$ go to other regions of Russia and $27.8 \%$ in other countries. In the Kaliningrad region, they are more focused on foreign tourism than on holidays in Russia: $70.7 \%$ travel to other countries and only $29.3 \%$ travel around Russia (http://akstat.gks.ru/wps/wcm/connect/rosstat/ts/akstat/resources/.htm; http://kalin ingrad. gks.ru/wps/wcm/connect/rosstat_ts/kaliningrad/ resources/).

To assess the impact of the typology of these regions and their border location on the population tourist orientation, including that of young people, a survey of students whose major is geography or tourism was conducted in the Immanuel Kant Baltic Federal University and Altai State University. The choice of these study fields was determined by a higher level of knowledge about countries and destinations so that to reduce the number of random responses and provide for comparability of the groups. The survey methodology is presented in the work of T. Studzieniecki (2018).

The question "Where would you go with a tourist purpose?" emphasized the tourist attractiveness of border countries and cross-border macro-regions. Altai students in their responses identified 43 countries, and Kaliningrad residents only 29, which partly indicates a better formation of tourist preferences, and higher proportion 
of people traveling abroad. Country preferences also have a significant difference. In the Altai Krai, countries such as Italy, USA, Norway and China received the highest preference among young people (from 10 to 12 answers out of 161 or from $6.2 \%$ to $7.5 \%$ of the respondents), while in the Kaliningrad region Germany was the top choice for 15 , $8 \%$ of respondents and Sweden for $14.2 \%$. Of greatest interest is the tourist orientation to the border countries and cross-border macroregions. Only 3.1\% of Altai respondents (in Kaliningrad, -o) mentioned bordering Kazakhstan.

In Kaliningrad, Poland was chosen by $2.5 \%$ of the respondents, and no one mentioned Lithuania. Why do such a small number of respondents choose bordering countries for traveling? The main reason relates to the fact that the majority of respondents have already visited these countries: $66.7 \%$ of respondents have visited Lithuania, and $65 \%$ have been to Poland. To this is added the so-called accessibility phenomenon, when a short-term trip to a neighboring country or region is easily made at any convenient time and with no planning.

For a cross-border macroregion, the situation is somewhat different. Less remote Asian countries, including Kazakhstan, Mongolia and China, account for $13 \%$ of potential tourist demand from the Altai Krai. Having added South Korea and Japan, this figure rises to $18 \%$. As for Kaliningrad, the potential demand for this region amounted to only 2.4\% (one response per China, Japan and South Korea).

The Baltic Sea region, which includes the Kaliningrad region as well, is more attractive for tourists: $38.4 \%$ of respondents would like to visit the Baltic region countries from Kaliningrad, and 6.2\% from the Altai Krai (Germany, ranked first, is likely to be visited by $5 \%$ of respondents). The distribution of potential tourist demand for the Baltic region from the side of Kaliningrad students was: Germany - 41.1\%, Sweden - 37.1\%, Denmark - 10.9\%, Poland - 6.5\% and Finland - 4.4\% (Figure 2).

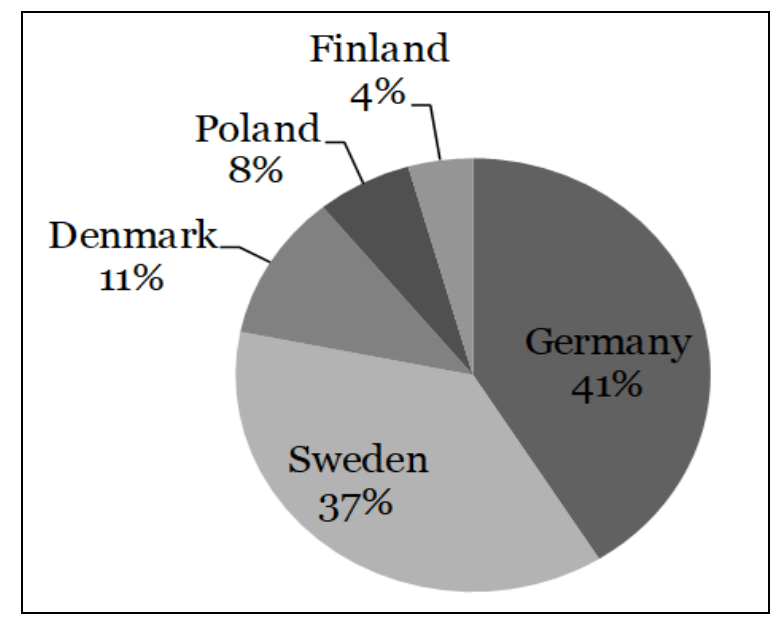

Figure 2. Structure of potential tourist demand for the Baltic Sea region countries by Kaliningrad students

As it can be seen from Figure 2, none of the respondents identified the Baltic countries (Lithuania, Latvia, and Estonia) as potential travel destinations, which is primarily associated with a negative assessment of the political situation and inter-ethnic relations, in particular official attitudes towards the Russian-speaking population.

When travelling, visa formalities cause the greatest troubles, - for $54.2 \%$ of all interviewed, while financial well-being $-45.8 \%$. For Altai students, these problems are 
more acute, given the distance from the main centers of tourism and the lack of visa centers and consulates. Even for visa-free countries, the cost of tours between regions is significantly different. For example, for the most popular outbound destination, the cost of an all included tour package in a five-star hotel in Turkey for 10 nights (other things being equal) in July 2018 was 61479 rubles from Kaliningrad and 77722 rubles from Barnaul which is 16 thousand rubles more.

For weekend tours there is also a big difference due to the remoteness of cities, which leads to higher travel costs and reduce the time spent in the tourist center. According to the Autodispatcher (https://www.avtodispetcher.ru/distance/), in the vicinity of $100 \mathrm{~km}$ from Kaliningrad's there are urban centers with a population of over 100 thousand: Elblag, Poland, is $102 \mathrm{~km}$ away, Klaipeda, Lithuania, is $136 \mathrm{~km}$ away and Berlin is $684 \mathrm{~km}$ away. In Barnaul, the situation is different because of the peripheral nature of the situation: the distance to Pavlodar in Kazakhstan is $517 \mathrm{~km}$, to Astana $1027 \mathrm{~km}$, and to Beijing - $4380 \mathrm{~km}$. The cost of air travel from Kaliningrad to Berlin is 9,278 rubles, and from Barnaul - 28,390 rubles.

Thus, residents of the Kaliningrad region, including students, have a number of advantages in implementing their tourism plans compared to residents of the Altai Krai and are more oriented towards neighboring countries.

\section{CONCLUSION}

The study was based on several ideas: firstly, the development of cross-border relations and participation in various forms of cross-border cooperation is an important tool for overcoming the negative consequences of the peripheral character of border regions, secondly, the types of border regions from core regions to transition crisis regions determine behavioral characteristics of the population.

At the same time, in the early stages of the development of border regions, tourism can be one of the mechanisms to start developing cross-border cooperation with subsequent transformation into a diversified economic center due to the multiplication effect and favorable investment climate. The border Kaliningrad region as a development corridor brings significant economic advantages in the development of cross-border relations in comparison with the Altai Krai, which belongs to peripheral resource regions. These advantages are transformed into a higher standard of living of the population, which ultimately determines the tourist preferences.

Research on tourism preferences can influence the adjustment of marketing policies with respect to a number of destinations, as well as the coordinated development of border areas of neighboring states, with the aim of diversifying the economy and creating favorable conditions for stimulating inbound tourism.

\section{REFERENCES}

Berdell, J., \& Ghoshall, An. (2015). US-Mexico border tourism and day trips: an aberration in globalization? Lat Am Econ Rev 24:15.

Cooper, A., \& Rumford, C. (2013). Monumentalising the border: bordering through connectivity. Mobilities 8(1), pp. 107-124.

Fedorov, G.M. (2018). Demographic Situation and Demographic Security in the Regions of Russia's Western Borderlands. Baltic Region, Vol. 10, № 3. pp. 119-135.

Friedmann, J. (1968). Regional development policy, 173 p. Mass.: The MIT Press, Cambridge.

Gumenyuk, I.S., \& Studzieniecki, T. (2018). Current and Prospective Transport Connections between Poland's Border Voivodeships and Russia’s Kaliningrad Region. Baltic Region, Vol. 10, № 2, pp. 114-132.

Ilies A. (Coord.), Baias S., Baias Iuliana, Blaga L., Buhaș S., Chiriac A., Ciocan Janeta, Dăncuș M., Deac Anca, Dragoș P., Dumitrescu G., Gaceu O., Godea I., Gozner Maria, Grama V., Herman G., Hodor N., Hurley P., Ilieș Dorina, Ilieș Gabriela, Ilieș M., Josan Ioana, Leșe G., Măduța F., Mojolic Diana, Morar 
C., Olaru M., Stașac M., Stupariu M., Sturza Amalia, Ștefănescu B., Tătar Corina, Vârnav R., Vlaicu M., \& Wendt J.A., (2014). Crisana-Maramures. Atlas geografic al patrimoniului turistic/ Geographical atlas of tourism heritage, 302 pp., Editura Universității din Oradea, ISBN 978-606-10-1298-5.

Ilies, D.C., Buhas, R., Ilies, M., Ilies, A., Gaceu, O., Pop, A.C., Marcu, F., Buhas, S.D., Gozner, M., \& Baias, S. (2018). Sport Activities and Leisure in Nature 2000 Protected Area - Red Valley, Romania. Journal of Environmental Protection and Ecology, 19, No 1, 367-372

Klemeshev, A.P., \& Federov, G.M. (2004). From an isolated exclave - to the "development corridor": alternatives to the Russian exclave in the Baltic, Kaliningrad: Kaliningrad State University, p. 253 (in Russ.).

Korneevets, V.S. (2010). Classification of border regions of Russia. Regional Studies, Smolensk: Smolensk Humanitarian University, no. 4, pp. 48-53 (in Russ.).

Korneevets V.S., \& Zaitseva, N.A., Dragileva I.I., Shabliauskene E.V. (2017). Assessment of the Prospects for Cross-Border Cooperation in the Conditions of the Changing Function of the Border. Eurasian Journal of Analitical Chemistry, 12 (Interdisciplinary Perspective on Sciences 7b), pp. 1375-1382.

Korneevets, V.S., Kropinova, E.G., \& Dragileva, I.I. (2015). The Current Approaches to the Transborder Studies in the Sphere of Tourism. International Journal of Economics and Financial Issues, 5 (Special Issue), pp. 65-73.

Martinez, O.J. (1994). The dynamics of border interaction. Glob Bound World Bound, 1:1-15, Routledge, London.

Mezhevich, N.M. (2002). Regional economic policy of the Russian Federation: the impact of cross-border cooperation on traditional and new implementation mechanisms. Saint-Petersburg: St Petersburg University, p. 172 (in Russ.).

Osmolovskay, L.G. (2016). Border functions as a factor of development of border regions and the formation of cross-border regions. IKBFU's Vestnik. Ser. Natural and medical sciences, no. 1, p. 45-54 (in Russ.).

Stoffelen, A., Ioannides, D., \& Vanneste D. (2017). Obstacles to achieving cross-border tourism governance: A multiscalar approach focusing on the German-Czech borderlands. Annals of Tourism Research, 64, pp. 126-138.

Studzieniecki T., Wanagos M., \& Urbanyi-Popiolek I. (2018). Kaliningrad Region as a Tourist Generating Area for the Baltic Sea Region. In Paper Prepared for the 32nd International Scientific Conference on Economic and Social Development - Odessa, 21-22 June 2018, pp. 139-147.

Studzińska, D., \& Domaniewski S. (2016). The border as a resource for the development of borderland: a comparative analysis of two polish urban centres at the external border of the European Union. Quaestiones Geographicae, 35(4).

Van der Velde, B. (1997). So Many Regions, So Many Borders. A Behavioral Approach in the Analysis of Border Effects. In Paper Prepared for the 37th European Congress of the European Regional Science Association, Rome.

Voloshenko, E.V., \& Voloshenko, K. Yu. (2018). Evaluating and Measuring the Security of Russia's Border Regions: Theory and Practice. Baltic Region, Vol. 10, no 3, pp. 96-118.

Zaitseva, N.A., Korneevets, V.S., Kropinova, E.G., Kuznetsova, T.Y., \& Semenova, L.V. (2016). Cross-border movement of people between Russia and Poland and their influence on the economy of border regions. International Journal of Economics and Financial Issues, Vol. 6, no. 4, pp. 1690-1695.

Zubarevich, N. (2010). Regional development and institutions: Russian spicifics. Regional Studies, Smolensk: Smolensk Humanitarian University, no. 2, pp. 3-14 (in Russ).

*** Department of the Federal State Statistics Service for the Altai Territory and the Altai Republic. Key performance indicators of tourist firms in the Altai Territory. Retrieved from: http://akstat.gks.ru/wps/ wcm/connect/rosstat_ts/akstat/resources/.htm [Accessed 11 July 2018].

*** Federal Customs Service. Retrieved from: http://www.customs.ru/index.php?option=com_content\&view $=$ article\&id=13858\&Itemid=2095 [Accessed 11 July 2018].

*** Ministry of Culture and Tourism of the Kaliningrad region, (2017). Annual report on the implementation and evaluation of the effectiveness of the state program of the Kaliningrad region "Tourism" for 2016. Retrieved from: http://tourism.gov39.ru/ [Accessed 16 May 2018].

*** National Touristic Rating, 2016. Retrieved from: http://russia-rating.ru/info/10950.html [Accessed 20 June 2017].

*** Official Website Auto Dispatcher. Retrieved from: https://www.avtodispetcher.ru/distance/ [Accessed 25 July 2018].

*** Regions of Russia. (2017). Main characteristics of the constituent entities of the Russian Federation. Retrieved from: http://www.gks.ru/bgd/regl/b17_14s/IssWWW.exe/Stg/.doc [Accessed 15 July 2018].

*** Territorial organ of the Federal State Statistics Service for the Kaliningrad region. Key performance indicators of travel companies. Retrieved from: http://kaliningrad.gks.ru/wps/wcm/connect/rosstat_ ts/kaliningrad/resources/ [Accessed 12 September 2017].

*** Tourism by numbers for the 12 months of 2016. Retrieved from: http://alttur22.ru/pages/turizm-v-cifrah-valtayskom-krae [Accessed 15 May 2018].

Submitted:

15.04.2019
Revised:

05.06.2019
Accepted and published online 27.06.2019 